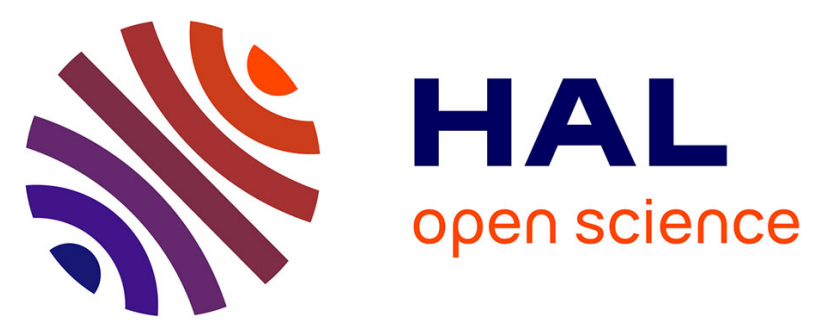

\title{
Absence of the del (exons 9-12) mutation in breast/ovarian cancer families outside of Mexican Hispanics
}

Diana Torres, Muhammad U. Rashid, Antje Seidel-Renkert, Jeffrey N. Weitzel, Ignacio Briceno, Ute Hamann

\section{To cite this version:}

Diana Torres, Muhammad U. Rashid, Antje Seidel-Renkert, Jeffrey N. Weitzel, Ignacio Briceno, et al.. Absence of the del (exons 9-12) mutation in breast/ovarian cancer families outside of Mexican Hispanics. Breast Cancer Research and Treatment, 2009, 117 (3), pp.679-681. 10.1007/s10549-0090383-4 . hal-00535354

\section{HAL Id: hal-00535354 https://hal.science/hal-00535354}

Submitted on 11 Nov 2010

HAL is a multi-disciplinary open access archive for the deposit and dissemination of scientific research documents, whether they are published or not. The documents may come from teaching and research institutions in France or abroad, or from public or private research centers.
L'archive ouverte pluridisciplinaire HAL, est destinée au dépôt et à la diffusion de documents scientifiques de niveau recherche, publiés ou non, émanant des établissements d'enseignement et de recherche français ou étrangers, des laboratoires publics ou privés. 


\title{
Absence of the BRCA1 del (exons 9-12) mutation in breast/ovarian cancer families outside of Mexican Hispanics
}

\author{
Diana Torres - Muhammad U. Rashid - Colombian Breast Cancer Study Group (COLBCS) - \\ Antje Seidel-Renkert · Jeffrey N. Weitzel • \\ Ignacio Briceno • Ute Hamann
}

Received: 17 March 2009/Accepted: 17 March 2009/Published online: 31 March 2009

(C) Springer Science+Business Media, LLC. 2009

Keywords BRCA1 - Genomic rearrangements · Exon 9-12 deletion · Ethnic groups

\section{To the editor}

The frequency and spectrum of germ line mutations in the high-penetrance breast cancer susceptibility genes BRCAI and $B R C A 2$ shows considerable variation by ethnic group. Most genetic epidemiological studies of the BRCA genes have been performed among Caucasian populations [1],

Diana Torres and Muhammad U. Rashid contributed equally to this work.

Colombian Breast Cancer Study Group (COLBCS): Angela Beltran, Viviana Ariza, Angela Umana, MSc., Fabian Gil (Pontificia Universidad Javeriana, Bogota); clinicians and hospitals: Jose Fernando Robledo, M.D., Jose Caicedo, M.D., Elías Quintero, M.D., Alejandro Orozco, M.D. (Country Clinic, Bogota); Mauricio Tawil, M.D., Lilian Torregrosa, M.D. (Pontificia Universidad Javeriana, Bogota).

M. U. Rashid · A. Seidel-Renkert · U. Hamann ( $\varangle)$

Deutsches Krebsforschungszentrum, Research Group Molecular Genetics of Breast Cancer, Im Neuenheimer Feld 580, 69120

Heidelberg, Germany

e-mail: u.hamann@dkfz-heidelberg.de

D. Torres · I. Briceno

Instituto de Genetica Humana, Pontificia Universidad Javeriana, Universidad de la Sabana, Bogota, Colombia

\section{U. Rashid}

Shaukat Khanum Memorial Cancer Hospital and Research Centre, Lahore, Pakistan

J. N. Weitzel

Department of Clinical Cancer Genetics, City of Hope, Duarte, CA, USA with the exception of a few studies involving other ethnic groups, such as Hispanics [2-4], Asians [5, 6], and African Americans [7-9]. In most of these studies only the frequencies of sequence detectable $B R C A$ mutations were reported and large genomic rearrangements including deletions and insertions of one or more exons, which account for $6-15 \%$ of all deleterious mutations in these genes have infrequently been considered [10-12].

Most $B R C A$ mutations are unique; however, few recurrent mutations with founder effects have been found in European, Hispanic, American and Asian populations [13]. In a recent study on Hispanic high-risk breast/ovarian cancer families of mainly Mexican descent from South California, Weitzel and colleagues reported the identification of a novel deletion of BRCA 1 exons 9 through 12 using multiplex quantitative differential polymerase chain reaction (PCR) analysis. The deletion was detected in 3.8\% of families negative for sequence detectable $B R C A$ mutations [14]. The large genomic rearrangement mutation is considered deleterious as it results in loss of critical functional domains as well as premature truncation of the BRCA1 protein. Given the relatively high prevalence of the deletion in this cohort, the authors suggest to include the screening for this mutation in the genetic testing strategy in Hispanic women without sequence detectable $B R C A$ mutations.

The spectra of recurrent sequence detectable $B R C A$ mutations, including some with founder effects in a cohort of Hispanic breast/ovarian cancer families of predominantly Mexican descent from the United States and in a cohort from Colombia have previously been shown to differ completely, with different common mutations being identified in the two populations [2,4]. In order to investigate, whether the novel BRCAl founder deletion is also specific for Hispanic families of Mexican descent or whether it also occurs in other Hispanic cohorts, we screened 229 cancer 
families from Colombia for its presence. Moreover, we assessed whether this mutation is present in families belonging to two other ethnic groups, including 255 Asian families from Pakistan and 54 Caucasian families from Germany. A description of the families under investigation is shown in Table 1. Among the Colombian, Pakistani and German families, 40, 146 and 54 families without sequence detectable $B R C A$-mutations, respectively, have been previously described [4, 5, 15-17]. The remaining families were newly recruited within an ongoing breast cancer case-control study in Colombia and a hereditary breast cancer study in Pakistan. All newly recruited families were screened for the presence of the common BRCA mutations specific for each of these ethnic groups (three founder mutations in Colombia; three founder and one recurrent mutation in Pakistan) and none were detected (unpublished data). The research study was approved by the local Ethics committees. BRCAl del (exons 9-12) mutation analysis was performed using a 3-primer PCR assay as previously described [14]. PCR products, including both positive and negative control samples, were separated by size on $1.5 \%$ agarose gels and visualized by ethidium bromide staining. The fragment sizes were $1,145 \mathrm{bp}$ for the wild type and 742 bp for the deletion mutation.
Table 1 Breast/ovarian cancer families from Colombia, Pakistan and Germany under investigation

\footnotetext{
${ }^{a}$ Including one family with a male breast cancer

${ }^{\mathrm{b}}$ Including two families with a male breast cancer
}

\begin{tabular}{|c|c|c|}
\hline Phenotype of families & No. of families & $\begin{array}{l}\text { No. of } B R C A 1 \text { del } \\
\text { (exons 9-12) carriers }\end{array}$ \\
\hline \multicolumn{3}{|l|}{ Hispanic breast/ovarian cancer families from Colombia } \\
\hline All families & 229 & $0 / 229$ \\
\hline \multicolumn{3}{|l|}{ Female breast cancer families (bilateral) } \\
\hline 1 case $(1)$ diagnosed $\leq 35$ years & 4 & \\
\hline 2 cases $(9)$ & 99 & \\
\hline 3 cases (4) & 68 & \\
\hline$\geq 4$ cases & 28 & \\
\hline \multicolumn{3}{|l|}{ Male breast cancer families } \\
\hline$\geq 1$ case $(1)$ & 1 & \\
\hline \multicolumn{3}{|l|}{ Breast-ovarian cancer families } \\
\hline$\geq 1$ breast cancer and $\geq 1$ ovarian cancer & 27 & \\
\hline \multicolumn{3}{|l|}{ Ovarian cancer families } \\
\hline$\geq 2$ cases & 2 & \\
\hline \multicolumn{3}{|l|}{ Asian breast/ovarian cancer families from Pakistan } \\
\hline All families & 255 & $0 / 255$ \\
\hline \multicolumn{3}{|l|}{ Female breast cancer families (bilateral) } \\
\hline 1 case $(2)$ diagnosed $\leq 30$ years & 135 & \\
\hline 1 case (10) diagnosed $\leq 50$ years & 10 & \\
\hline 2 cases (1) with $\geq 1$ diagnosed $\leq 50$ years & 31 & \\
\hline 3 cases (2) with $\geq 1$ diagnosed $\leq 50$ years & 18 & \\
\hline$\geq 4$ cases with $\geq 1$ diagnosed $\leq 50$ years & 9 & \\
\hline \multicolumn{3}{|l|}{ Male breast cancer families } \\
\hline$\geq 1$ case of male breast cancer & 11 & \\
\hline \multicolumn{3}{|l|}{ Breast-ovarian cancer families } \\
\hline$\geq 1$ breast cancer and $\geq 1$ ovarian cancer & 18 & \\
\hline \multicolumn{3}{|l|}{ Ovarian cancer families } \\
\hline 1 case diagnosed $\leq 45$ years & 21 & \\
\hline 2 cases with $\leq 1$ case diagnosed before 45 years & 2 & \\
\hline \multicolumn{3}{|l|}{ Caucasian breast/ovarian cancer families } \\
\hline All families & 54 & $0 / 54$ \\
\hline \multicolumn{3}{|l|}{ Female breast cancer families (bilateral) } \\
\hline 3 cases (3) with $\geq 1$ diagnosed $\leq 50$ years & $19^{\mathrm{a}}$ & \\
\hline$\geq 4$ cases (6) with $\geq 1$ diagnosed $\leq 50$ years & $24^{\mathrm{b}}$ & \\
\hline \multicolumn{3}{|l|}{ Breast-ovarian cancer families } \\
\hline$\geq 1$ breast cancer and $\geq 1$ ovarian cancer & 11 & \\
\hline
\end{tabular}


The present study included 538 affected individuals from breast and/or ovarian cancer families. The mean ages of female breast cancer onset in Colombian, Pakistani and German patients were 50 years (range 23-83, $n=224$ ), 30 years (range 19-70, $n=218$ ) and 44 years (range $24-70, n=54)$, respectively. The mean age of ovarian cancer onset was 54 years (range 34-71, $n=4$ ) for Colombian patients and 33 years (range 22-48, $n=26$ ) for Pakistani patients.

None of the 538 analyzed samples carried the BRCA1 del (exons 9-12) mutation (Table 1). This finding suggests that this mutation is not present or is present at an extremely low frequency in Hispanic families from Colombia as well as in Pakistani and German populations.

The absence of the BRCAl del (exons 9-12) mutation in Hispanic families from Colombia shows that this mutation does not contribute to hereditary breast/ovarian cancer in this population, nor in Pakistani and German populations. Our data confirm our previous finding that the spectra of the $B R C A$ founder mutations differ between Hispanic families of Mexican origin from the United States and families from Colombia. These findings provide further evidence that specific risk assessment strategies for the different Hispanic populations in South America and in the United States need to be developed.

Acknowledgments We are indebted to all women who had participated in this study. We gratefully acknowledge support by the physicians in Pakistan and Germany. This work was financed by the Deutsches Krebsforschungszentrum, Heidelberg and in part by a grant of Dr. Weitzel from the California Breast Cancer Research Program.

\section{References}

1. Szabo CI, King MC (1997) Population genetics of BRCA1 and BRCA2. Am J Hum Genet 60(5):1013-1020

2. Weitzel JN, Lagos V, Blazer KR, Nelson R, Ricker C, Herzog J, McGuire C, Neuhausen S (2005) Prevalence of BRCA mutations and founder effect in high-risk Hispanic families. Cancer Epidemiol Biomarkers Prev 14(7):1666-1671. doi:10.1158/10559965.EPI-05-0072

3. Jara L, Ampuero S, Santibanez E, Seccia L, Rodríguez J, Bustamante M, Martínez V, Catenaccio A, Lay-Son G, Blanco R, Reyes JM (2006) BRCA1 and BRCA2 mutations in a South American population. Cancer Genet Cytogenet 166(1):36-45. doi:10.1016/j.cancergencyto.2005.08.019

4. Torres D, Rashid MU, Gil F, Umana A, Ramelli G, Robledo JF, Tawil M, Torregrosa L, Briceno I, Hamann U (2007) High proportion of BRCA1/2 founder mutations in Hispanic breast/ ovarian cancer families from Colombia. Breast Cancer Res Treat 103(2):225-232. doi:10.1007/s10549-006-9370-1

5. Rashid MU, Zaidi A, Torres D, Sultan F, Benner A, Naqvi B, Shakoori AR, Seidel-Renkert A, Farooq H, Narod S, Amin A, Hamann U (2006) Prevalence of BRCA1 and BRCA2 mutations in Pakistani breast and ovarian cancer patients. Int $\mathrm{J}$ Cancer 119(12):2832-2839. doi:10.1002/ijc.22269

6. Liede A, Narod SA (2002) Hereditary breast and ovarian cancer in Asia: genetic epidemiology of BRCA1 and BRCA2. Hum Mutat 20(6):413-424. doi:10.1002/humu.10154

7. Hughes C, Gomez-Caminero A, Benkendorf J, Kerner J, Isaacs C, Barter J, Lerman C (1997) Ethnic differences in knowledge and attitudes about BRCA1 testing in women at increased risk. Patient Educ Couns 32(1-2):51-62. doi:10.1016/S0738-3991(97) 00064-5

8. Hughes C, Lerman C, Lustbader E (1996) Ethnic differences in risk perception among women at increased risk for breast cancer. Breast Cancer Res Treat 40(1):25-35. doi:10.1007/BF01806000

9. Croyle RT, Lerman C (1999) Risk communication in genetic testing for cancer susceptibility. J Natl Cancer Inst Monogr 25:59-66

10. Gad S, Caux-Moncoutier V, Pages-Berhouet S, Gauthier-Villars M, Coupier I, Pujol P, Frénay M, Gilbert B, Maugard C, Bignon YJ, Chevrier A, Rossi A, Fricker JP, Nguyen TD, Demange L, Aurias A, Bensimon A, Stoppa-Lyonnet D (2002) Significant contribution of large BRCA1 gene rearrangements in 120 French breast and ovarian cancer families. Oncogene 21(44):6841-6847. doi:10.1038/sj.onc. 1205685

11. Casilli F, Tournier I, Sinilnikova OM, Coulet F, Soubrier F, Houdayer C, Hardouin A, Berthet P, Sobol H, Bourdon V, Muller D, Fricker JP, Capoulade-Metay C, Chompret A, Nogues C, Mazoyer S, Chappuis P, Maillet P, Philippe C, Lortholary A, Gesta P, Bézieau S, Toulas C, Gladieff L, Maugard CM, Provencher DM, Dugast C, Delvincourt C, Nguyen TD, Faivre L, Bonadona V, Frébourg T, Lidereau R, Stoppa-Lyonnet D, Tosi M (2006) The contribution of germline rearrangements to the spectrum of BRCA2 mutations. J Med Genet 43(9):e49. doi: 10.1136/jmg.2005.040212

12. Palma MD, Domchek SM, Stopfer J, Erlichman J, Siegfried JD, Tigges-Cardwell J, Mason BA, Rebbeck TR, Nathanson KL (2008) The relative contribution of point mutations and genomic rearrangements in BRCA1 and BRCA2 in high-risk breast cancer families. Cancer Res 68(17):7006-7014. doi:10.1158/0008-5472. CAN-08-0599

13. Ferla R, Calo V, Cascio S, Badalamenti G, Carreca I, Surmacz E, Colucci G, Bazan V, Russo A (2007) Founder mutations in BRCA1 and BRCA2 genes. Ann Oncol 18(Suppl 6):vi93-vi98. doi:10.1093/annonc/mdm234

14. Weitzel JN, Lagos VI, Herzog JS, Judkins T, Hendrickson B, Ho JS, Ricker CN, Lowstuter KJ, Blazer KR, Tomlinson G, Scholl T (2007) Evidence for common ancestral origin of a recurring BRCA1 genomic rearrangement identified in high-risk Hispanic families. Cancer Epidemiol Biomarkers Prev 16(8):1615-1620. doi:10.1158/1055-9965.EPI-07-0198

15. Hamann U, Brauch H, Garvin AM, Bastert G, Scott RJ (1997) German family study on hereditary breast and/or ovarian cancer: germline mutation analysis of the BRCA1 gene. Genes Chromosomes Cancer 18(2):126-132. doi:10.1002/(SICI)1098-2264 (199702)18:2<126:AID-GCC7>3.0.CO;2-4

16. Hamann U, Haner M, Stosiek U, Bastert G, Scott RJ (1997) Low frequency of BRCA1 germline mutations in 45 German breast/ ovarian cancer families. J Med Genet 34(11):884-888. doi: 10.1136/jmg.34.11.884

17. Hamann U, Liu X, Lange S, Ulmer HU, Benner A, Scott RJ (2002) Contribution of BRCA2 germline mutations to hereditary breast/ovarian cancer in Germany. J Med Genet 39(3):E12. doi: 10.1136/jmg.39.3.e12 